\title{
KORUPSI DALAM PERSPEKTIF FILSAFAT HUKUM ISLAM
}

\section{Firmansyah}

Fakultas Syariah Institut Agama Islam Negeri Palopo

\begin{abstract}
Act of corruption is the act Dirty, cheating and bad Judging from the positive law and legal From the legal perspective Islam faktor causes of corruption there are prayer external (opportunities, Needs ) and internal AS namely greed And its reduced intelligence spiritual (religious problem ) or word heart identifiable or in objectivation From prayer.for the future setting on the problem of corruption should be accommodated religious hearts by making anti - corruption jurisprudence, order Becoming Guidelines and Reference and Rules paled not animates positive Yang was born and penalization Right to review Performers Corruptor for the benefit considerations .
\end{abstract} Keywords: Corruption, Islamic Law.

\begin{abstract}
Abstrak
Tindakan korupsi adalah tindakan kotor, curang dan buruk Dilihat dari hukum positif dan hukum Dari sudut pandang hukum Islam faktor-faktor penyebab korupsi ada doa eksternal (peluang, Kebutuhan) dan internal AS yaitu keserakahan Dan kecerdasan spiritualnya berkurang (masalah agama) atau kata hati dapat diidentifikasi atau diobjektivasi Dari doa. Untuk masa depan pengaturan masalah korupsi harus diakomodasikan hati keagamaan dengan membuat yurisprudensi anti-korupsi, ketertiban menjadi Pedoman dan Referensi dan Aturan yang pucat tidak menjiwai positif Yang dilahirkan dan hukuman Hak untuk meninjau Performer Corruptor untuk pertimbangan manfaat.
\end{abstract}

Kata Kunci : Korupsi, Hukum Islam

\section{PENDAHULUAN}

Korupsi beberapa dekade ini merupakan isu sentral dalam penegakan hukum yang seakan menjadi hal yang biasa di Negeri ini yang tentunya akan berdampak bagi kesejahtraan rakyat dan memberikan pendidikan yang buruk bagi masyarakat sehingga pada akhirnya membuat mereka menjadi apatis, apalagi sanksi bagi pelaku korupsi sangat ringan sehingga tidak ada efek jera, bukannya mengurangi tetapi malah menambah kuantitas terjadinya korupsi, sehingga tampak adanya ketidakadilan jika dibandingkan dengan tindak pidana pencurian biasa.

Berdasarkan hal tersebut dibutuhkan peran serta segala pihak untuk memerangi korupsi, tapi tentunya yang paling bertanggungjawab sebagai garda terdepan adalah lembaga penegak hukum seperti KPK, Kejaksaan, kepolisian, selain itu pemerintah mestinya memberi edukasi kepada masyarakat bahwa korupsi itu adalah sesuatu yang buruk, apalagi korupsi banyak melibatkan orang-orang yang mestinya menjadi teladan bagi masyarakat. Selain itu dibutuhkan terobosan agama untuk menjadikan korupsi sebagai musuh bersama yang pengaturannya jelas secara fikih dalam agama, tetapi persolan tentang korupsi baik dalam Al-qur ${ }^{\text {ee } a n, ~ h a d i s ~ m a u p u n ~}$ 
kitab-kitab fikih klasik tidak ditemukan, ${ }^{1}$ namun peran agama tetap di butuhkan baik secara kelembagaan maupun secara personal dalam memerangi masalah korupsi, secara kelembagaan adalah agama mesti memberi penjelasan secara edukasi kepada masyarakat bahwa korupsi itu sebuah hal yang dilarang dalam agama, sedangkan secara personal mestinya nilainilai agama dijadikan pedoman sehingga seseorang bisa terhindar dari perbuatan korupsi,

Tujuan penulis ini mengangkat masalah korupsi karena korupsi seakan menjadi hal yang biasa serta menjadi problem sosial yang massif di Indonesia, nota-bene dilaku-kan oleh orangorang yang secara agama baik, tetapi tetap saja melakukan korupsi, selain itu persoalan lain adalah pengaturan korupsi dalam agama yang yang masih absurd berbeda dengan pencurian yang jelas pengaturannya dalam nash Al-qurean (Al-Maidah ayat:38), maka menurut penulis masalah korupsi ini perlu dikaji dari pers-pektif filsafat hukum islam supaya hakekat dan sumber dari korupsi tersebut dapat diketahui dan ada solusi untuk mencegah seseorang dari melakukan korupsi dan ber-dasarkan hal tersebut maka penulis ke-mudian mengkaji secara filasfat seperti apa hakekat dari korupsi ini baik ditinjau dari perspektif hukum positif maupun hukum Islam, mengapa orang melakukan korupsi, serta seperti apa penilaian agama terkait dengan korupsi.

\section{PEMBAHASAN}

\section{Korupsi dalam Perspektif hukum Positif dan Hukum Islam}

\section{a. Korupsi dalam Perspektif Hukum Positif}

Secara harfiah korupsi berasal dari bahasa latin "corruption ” yang berarti sesuatu yang rusak, busuk, bejad, dan tidak jujur yang disangkutpautkan dengan keuangan, korupsi dalam Black law dictionary adalah suatu perbuatan yang dilakukan dengan maksud untuk memberi suatu keuntungan yang tidak sesuai dengan kewajiban resmi dan hak-hak dari pihak-pihak lain, secara salah menggunakan jabatannya atau karakternya untuk mendapatkan suatu keuntungan untuk dirinya sendiri atau untuk orang lain, bersamaan dengan kewajibannya dan hak-hak dari pihak lain. $^{2}$

Adapun pengertian korupsi dalam Undang-Undang No. 31 Tahun 1999 Tentang Tidak pidana korupsi yaitu :

1) Kerugian perekonomian negara, melawan hukum dan penyalahgunaan wewenang, karena jabatan.

\footnotetext{
${ }^{1}$ Suyitno, Korupsi, Hukum dan Moralitas Agama, (Yogyakarta:Gama Media, 2006), hlm. 133.

${ }^{2}$ Marwan Effendy, Temu nasional komunitas masyarakat sriwijaya dengan tema strategi penanggulangan korupsi secara integral dan sistemik, 9 juni 2012 di Yogyakarta, hlm 5
} 
2) Suap-menyuap (sogokan atau pelicin), seperti: menyuap pegawai negeri yang berhubungan dengan jabatannya, hakim, advokat serta hakim dan advokat yang menerima suap.

3) Penggelapan dalam jabatan.

4) Pemerasan.

5) Perbuatan curang, seperti pemborong, pengawas, rekanan TNI/Polri, serta pegawai negeri.

6) Benturan kepentingan dalam pengadaan Barang maupun Jasa.

7) Grativikasi (pemberian hadiah). ${ }^{3}$

\section{b. Korupsi Dalam Perspektif Islam}

Persoalan tentang korupsi tidak ditemui secara eksplisit baik dalam Al-quran, Hadis maupun kitab-kitab hukum klasik. Hal tersebut menjadi persoalan, karena untuk memahami masalah korupsi secara konfrehensif harus dibuatkan sebuah konsep fikih. seperti halnya masalah pencurian yang jelas hukumnya dalam Al-qurean (QS Al-Maidah (5):38) yaitu: "Adapun orang laki-laki maupun perempuan yang mencuri, potonglah tangan keduanya (sebagai) balasan atas perbuatan yang mereka lakukan dan sebagai siksaan dari Allah. Dan Allah Maha perkasa, Maha bijaksana." Secara substansi permasalahan korupsi dapat diidentifikasi dengan beberapa indikator antara lain:

Pertama, kejahatan ko-rupsi dalam Islam sangat erat dengan kehi-dupan seseorang yang sering melakukan perbuatan kotor atau najis (rijsun min amalaishaithan) yang dihadirkan dari perbuatan bohong atau tidak jujur. Kedua, kejahatan korupsi dalam Islam erat kaitannya dengan seseorang yang suka melakukan penipuan atau tidak memiliki komitmen pada amanah yang dianugrahkan. Ketiga, kejahatan korupsi juga berkaitan dengan praktek mengurangi timbangan dalam suatu praktek jual beli, tidak jauh berbeda bahwa kejahatan korupsi didukung oleh perilaku mencampuradukkan antara hak dan bathil, benar dan salah. Keempat, dari aspek psikologis, kejahatan korupsi timbul akibat timbulnya manusia-manusia tamak dan rakus, mereka yang memiliki sifat tidak mau ber syukur dan selalu mementingkan kepentingan diri dan kelompoknya. Kelima, kejahatan korupsi timbul karena maraknya pola hidup yang senang dengan berbagai kenikmatan dunia dan kurang peduli pada kepentingan umum.

${ }^{3}$ Komisi Pemberantasan Korupsi, Memahami untuk membasmi, cetakan ke-dua (Jakarta: Perpustakaan nasional, 2006), hlm 20-21 
Adapun pengelompokan korupsi dapat diidentikkan dengan perbuatan kotor atau najis dalam ajaran islam yaitu: Pertama, perbuatan korupsi sebagai najis yang ringan (mukhoffafah) korupsi jenis ini lebih cende-rung pada perihal atau sektor swasta, seperti Pasal 21 tentang penyuapan di sektor swasta, Pasal 22 tentang penggelapan kekayaan disektor swasta, Pasal 23 tentang pencuciann hasil-hasil kejahatan, dan Pasal 24 tentang penyembunyian. Kedua, perbuatan korupsi sebagai najis menengah (mutawasithoh) korupsi jenis ini cenderung berdampak pribadisosial, seperti Pasal 18 yaitu memperdagangkan pengaruh, Pasal 19 tentang penyalahgunaan fungsi dan Pasal 20 tentang memperkaya diri secara tidak sah. Ketiga, perbuatan korupsi sebagai najis yang berat (mugholadoh) korupsi jenis ini berdampak pada kemaslahatan nasional atau bangsa dan internasional secara langsung, seperti dalam Pasal 15 tentang penyuapan pejabat-pejabat publik nasional, Pasal 16 penyuapan pejabat-pejabat publik asing dan pejabat-pejabat organisasiorganisasi Internasional publik dan Pasal 17 tentang penggelapan. Berbagai kategori diatas tidak serta merta menafikan adanya keringanan pada pelaku tindak pidana korupsi, adanya penggolongan tersebut didasarkan pada signifikasi dampak dari perbuatan korupsi yang dilakukan. $^{4}$

\section{Faktor Orang melakukan korupsi}

Beberapa faktor-faktor orang melakukan korupsi yaitu:

1. Keserakahan (Greeds), berkaitan dengan adanya perilaku serakah yang secara potensial ada didalam diri setiap orang.

2. Kesempatan (Opportunities), berkaitan dengan keadaan organisasi atau instansi atau masyarakat yang sedemikian rupa sehingga terbuka kesempatan bagi seseorang untuk melakukan kecurangan terhadapnya.

3. Kebutuhan (Needs), berkaitan dengan faktor-faktor yang dibutuhkan oleh individuindividu untuk menunjang hidupnya yang wajar.

4. Dipamerkan/pengungkapan (Exposu res), berkaitan dengan tindakan atau konsekuensi yang akan di-hadapi oleh pelaku kecurangan apabila ditemukan pelaku melakukan kecurangan. ${ }^{5}$

${ }^{4}$ Jawahir Thontowi, seminar nasional dan call for paper dengan tema "peran perguruan tinggi atas destruksi moral perilaku koruptif: mengikis atau membudayakan?, Rabu, 4 Desember 2013 di ruang Auditorium gedung C lt.3, kampus Universitas Pekalongan. Jawa Tengah, hlm 6-10

${ }^{5}$ Marwan Effendi, Temu nasional ...op. cit., hlm 3 
Dari sekian banyak penyebab orang melakukan korupsi seperti dijelaskan diatas penulis kemudian mengklasifikasikan bahwa penyebab orang melakukan korupsi disebabkan oleh faktor eksternal serta faktor internal (keserakahan), tetapi bagi penulis yang juga berpengaruh adalah faktor internal, disini faktor internal yang penulis maksud adalah tidak berfungsinya kecerdasan yang dimiliki orang tersebut yang oleh Ari Ginanjar disebut sebagai kecerdasan spritual, sehingga menyebabkan seseorang serakah. Kecerdasan spritual itu memiliki sebuah kebenaran sejati yang bersumber dari suara hati, yang tidak bisa ditipu oleh siapa pun atau oleh apapun termasuk kita sendiri.

Mata hati ini dapat mengungkap kebenaran hakiki yang tampak dihadapan mata, bahkan kata seorang sufi Jalaluddin Rumi “ Mata hati punya kemampuan 70 kali lebih besar untuk melihat kebenaran dari pada dua indera penglihatan. "6 Hati nurani tadi yang oleh Ary ginanjar disebut God-Spot yang mana seringkali ter-tutup oleh berbagai belenggu yang menye-babkan orang menjadi buta hati, sehingga seseorang tidak mampu lagi men-dengar informasi-informasi yang maha penting yang bersumber dari hatinya sendiri yang mengakibatkan seseorang terperosok ke dalam kemaksiatan ${ }^{7}$, seperti halnya jika kita kaitkan dengan korupsi.

Berbagai fenomena korupsi yang terjadi dinegara kita yang jika kita pandang sepintas korupsi itu dilakukan oleh orangorang yang secara agama baik, misalnya kasus korupsi pengadaan al-Qurean serta kasus yang melibatkan petinggi partai islam dinegara kita, hal ini sungguh sebuah ironi yang mestinya mereka menjadi teladan tetapi justru sebaliknya, ketika hal itu kita kaji maka menurut penulis yang bermasalah adalah kecerdasan spritualnya dalam hal ini salah satunya adalah masalah shalatnya yang mestinya menjadi perisai dari perbuatan maksiat, karena dalam agama jelas disebutkan bahwa "Sesungguhnya Shalat mencegah perbuatan keji dan mungkar (Surat Alankabut: 45)”. Ketika kita mengkaji ayat diatas mestinya shalat itu menjadi perisai yang melindungi dan mencegah seseorang dari melakukan perbuatan yang dilarang tapi faktanya sekarang korupsi banyak juga dilakukan oleh orang-orang yang dianggap sholeh seperti apa yang terjadi pada partai Islam di negeri ini, begitupun adanya korupsi mengenai pengadaan Al-qurean.

Penulis kemudian berkesimpulan bahwa penyebabnya utama mereka melakukan korupsi adalah ketidakbermaknaan dari shalatnya dan mesti dipertanyakan shalatnya, harusnya nilai-nilai dari shalat terinternalisasi dalam diri sehingga bisa menjadi perisai dan shalat yang seperti ini

\footnotetext{
${ }^{6}$ Ary Ginanjar Agustian, Emotional Spritual Quotient, (Jakarta : Arga ,2001),hlm xxxvii

${ }^{7}$ Ibid,hlm. 204
} 
adalah shalat yang dalam agama disebut shalat yang khusuk, dimana shalat itu hadir tidak hanya sebagai sebuah ritual tapi betul-betul hadir untuk mendapat ridho dari sang pencipta, jika kita melihat shalat-shalat yang dilakukan pada zaman dulu Nabi dan para sahabat betul-betul khusuk dalam me-laksanakan shalat, kita bisa melihat Ali dan Umar pada saat shalat mereka dibunuh tapi hal itu tidak dirasakan sekalipun karena begitu khusuk dalam melakukan shalat, sehingga nilainilai shalatnya itu termanifestasi dalam perilaku mereka. Melalui shalat pula maka akan menjadi kunci dari pembangunan dan pelatihan prinsip seperti:

1. Membentuk dan melatih rasa aman, ada ucapan"Sesungguhnya shalatku, ibadahku, hidupku, dan matiku semata hanya untuk Allah seru sekalian alam”. Ucapan tadi sunggguh-sung guh menciptakan rasa aman dan tentram, bahwa segala kegiatan seseorang mulai dari shalatnya sampai matinya hanya semata-mata hanya untuk Allah Yang Maha Esa adalah suatu komitmen jiwa manusia dalam rangka menghadapi kondisi lingkungan yang serba tidak bisa diramalkan, olehnya itu ucapan-ucapan tadi adalah suatu penetapan misi dan prinsip hidup seseorang baik dalam berfikir maupun bertindak, sehingga membentuk rasa aman yang sempurna lagi melalui ruku ${ }^{\text {ee }}$ dan sujud yang artinya adalah komitmen yang dilakukan secara fisik dan mental, selanjutnya berharap akan ada hasil dari Allah yang dilukiskan melalui tahiyyat yang menyatakan bahwa penghorhormatan, keberkahan dan kesejahtraan hanyalah dari dan milik Allah.

2. Melatih dan membentuk kepercayaan diri serta motovasi, ucapan Allahu Akbar adalah suatu pengakuan bahwa hanya Allah-lah yang memiliki kebesaran, sifat kebesaran Allah yang akan mengisi jiwanya untuk selalu meraih kebesaran dan kemenangan yang menghasilkan pribadi yang ber-mental juara, mendidik manusia agar selalu meniru dan berprinsif yang baik ketika melakukan setiap kegiatan serta membangun rasa percaya diri serta motivasi.

3. Melatih kebijaksanaan, kebijaksaan adalah menyelarasakan antara satu suara hati dengan suara hati yang lain, doa dan gerakan shalat merupakan suatu penggabungan berbagai sifatsifat Allah dalam satu kesatuan tauhid, kita tidak cukup dengan menyatakan beriman saja, tetapi harus melakukan suatu langkah nyata ini dilambangkan dengan doa yang dilakukan secara bersamaan, begitu pula perjuangan tidak cukup hanya duduk, hanya berdiri, haruslah dinamis dan berkelanjutan dalam satu kesatuan gerak yang menyeluruh, ia harus bersinergi dan memiliki kesadaran akan tanggungjawab 
sosial yang diembannya, hal ini dilatih pula melalui pernyataan dan doa didalam shalawat Nabi dan Rasul serta saudara-saudara yang beriman, kemudian dilanjutkan oleh salam ke kanan dan ke kiri, inilah pelatihan ketangguhan sosial.

4. Melatih integritas, dimana integritas adalah sebuah kesungguhan, kejujuran dan komitmen, integritas bekerja karena dorongan suara hati, bukan karena orang lain. Shalat lima waktu secara disiplin tanpa diawasi oleh orang lain adalah sebuah pelatihan integritas yang sesungguhnya yang akan melahirkan pribadi yang memiliki integritas yang kuat, ia mampu memahami arti shalat yang sesungguhnya. Begitu pula bacaan didalam shalat seperti doa iftitah, surat alfatihah, rukuee, sujud dan tahiyyat semua itu pada akhirnya akan mela hirkan seseorang yang memiliki integritas yang sangat luar biasa, karena ia hanya berpegang kepada Allah semata yang selalu meng-awasinya.

5. Melatih kepemimimpinan, dimana kepemimpinan adalah sebuah pengaruh yang berangkat dari sebuah kepercayaan yang terbentuk dari sifat Rahman dan Rahim-Nya, shalat adalah suatu bentuk pelatihan mental yang menghasilakn manusia yang ber-sifat rahman dan rahim, yang dibentuk dengan ucapan "Bismillahirrahmanirrahim" sebelum bertindak, pikiran serta doktrin terbentuk melalui shalat yang dilakukan secara disiplin setiap hari, kemudian dilatih dan dibentuk integritasnya melalui shalat yang tulus dimana hal ini akan membangun suatu kepercayaan serta sebuah teladan yang patut diikuti. Ketika duduk pada tahiyyat akhir, ia dibentuk untuk selalu memikirkan dan mendoaeeakan orang-orang disekelilingnya, dan dilatih untuk menghargai dan menghormati pimpinannya (imam), menghargai Nabi dan Rasulnya (shalawat), ia diwajibkan untuk memiliki kepribadian yang jelas yaitu dengan mengucapkan dua kalimat syahadat sebagai misi utama-nya sehingga pengikutnya akan jelas membaca dan mengetahui ke mana arah kepemimpinannya itu, disinilah shalat merupakan pelatihan kepemimpinan yang sesungguhnya dari Allah Swt, sang pencipta alam semesta dan sekaligus "Pemimpin" dari alam semesta raya beserta seluruh isinya. ${ }^{8}$

Selain itu dalam setiap shalat kita selalu membaca surat Al-Fatihah mestinya ayat-ayat yang ada didalamnya itu diinternalisasi-kan dalam diri sehingga dapat membentuk pribadi yang sempurna, olehnya itu ada beberapa istilah yang penting dipahami dalam surat Al-Fatihah yaitu:

\footnotetext{
${ }^{8}$ Ibid, hlm 206-209
} 
1. Bismillahirrahmanirrahim, yang artinya "Dengan nama Allah Yang Maha Pengasih lagi Maha Penyayang", sebagai pembuka: mulailah atas nama Allah, dimana prinsip ini akan menyadarkan diri untuk selalu bersikap rahman dan rahim kepada setiap orang agar selalu memiliki prinsip memberi dan memulai.

2. Alhamdulilahirabbil Alamiin. Yang artinya "segala puji bagi Allah Tuhan semesta alam”, memuji Allah: sebagai sumber kecerdasan emosi dan spiritual, dimana anda akan selalu merasa dalam curahan Rahmat Allah, pemilik alam semesta raya ini, anda akan merasa tentram dan merasa telindungi karena didasari oleh kepercayaan bahwa anda bekerja untuk mensejahterakan bumi milik Allah ini, bersedia untuk menggunakan seluruh potensi diri secara maksimal dalam rangka menjalankan tugas sebagai Rahmatan lil „alamin, selalu meng-ingat semua sifat-sifat Allah sebagai landasan dari kecerdasan emosi dan spiritual.

3. Arrahmaanirrahim, yang artinya Yang Maha Pengasih lagi Maha Penyayang, sebagai bekal: sikap memberi, dimana untuk meraih suatu kepercayaan harus didasari oleh sikap Rahman dan Rahim kepada orang lain, tidak merugikan orang lain dan selalu berusaha membantu dan menolong orang lain, iniah dasar keberhasilan hubungan antar manusia yang membawa kepada suatu ketang-guhan sosial.

4. Maaliki Yaumiddin, yang artinya Pemilik/raja hari pembalasan, sebagai tujuan : visi, dimana selau berorientasi pada masa depan dan memiliki harapan yang jelas serta memiliki perencanaan untuk setiap langkah yang akan dibuat sehingga akan memiliki suatu kesadaran penuh bahwa cara untuk meraih keberhasilan tidaklah ditempuh dengan cara yang buruk, tetapi harus atas nama Allah.

5. Iyyaka $\mathrm{Na}^{e e}$ budu Wa Iyyaka Nasta ${ }^{e e}$ iin, Yang artinya hanya kepada-MU kami mengabdi dan hanya Kepada-MU kami mohon pertolongan, sebagai pemelihara prinsip: integritas, dimana berprinsip tunggal hanya kepada Allah Yang Maha Esa, bekerja secara sungguh-sungguh dan selalu bersikap jujur, memiliki komitmen dan selalu konsisten dalam mencapai tujuan karana selau merasa dilihat Allah.

6. Ihdinash Shiraathal Mustaqiin, yang artinya tunjukilah kami jalan yang luas dan lurus, sebagai pedoman: aplikasi, dimana ini adalah suatu langkah pelaksanaan secara total dari suatu visi yang telah dilandasi oleh karakter yang kokoh dan prinsip yang teguh, 
disinilah letak perjuangan yang sesungguhnya. Langkah Islam yang diaplikasikan secara total.

7. Shiraathal Ladziina An amta ,alaihim, Ghairil Maghdhuubi „Alaihim Waladh Dhaliin, yang artinya jalan orang-orang yang Engkau beri nikmat, bukan jalan mereka yang dimurkai, bukan pula jalan yang sesat, sebagai penyempurnaan: asahlah gergaji, Dimana ditengah perjalanan hidup ini teruslah asah hati anda, pikiran dan pelaksanaan anda secara terus-menerus, sehingga terbentuk suatu tingkatan yang baru yang lebih baik dan sempurna, terus evaluasi pikiran, hati dan pelaksanaan kerja anda agar tetap berada pada tangga yang lurus yang di Ridhoi Allah.

8. Amiin, yang artinya kabulkanlah, sebagai rasa syukur : ikhlas, dimana tetaplah ikhlas untuk menerima segala hasil yang telah dicapai, apapun hasilnya, terima dengan baik karena semua datang dari Allah, apabila belum merasa puas jangan langsung menyalahkan nasib, baca dan pelajarilah (Iqra) pasti ada sesuatu hal yang masih kurang dan belum dilakukan.

Setiap membaca Al-Fatihah pergunakanlah seluruh suara hati anda untuk menyerap dan sekaligus melatih dan mempertajam kecerdasan spiritual anda, ${ }^{9}$ jadi menurut saya setelah mengetahui sebab orang yang kita anggap shaleh melakukan korupsi maka tawaran saya adalah untuk persoalan internal maka yang mesti diperhatikan adalah masalah shalat-nya, saya yakin ketika shalatnya baik maka sesuai janji Allah maka shalatnya itu akan menjadi perisai dari perbuatan keji dan munkar, salah satunya adalah menghindarkan seseorang dari perbuatan korupsi.

Persoalan Korupsi dalam Persfektif Filsafat Hukum Islam Dari pemahaman tentang pengertian korupsi diatas ditinjau dari hukum positif maupun hukum islam, maka jelas bahwa persoalan korupsi tidak diatur secara khusus dalam nash Al-quree an maupun kitab-kitab fikih klasik, ${ }^{10}$ Jika kita bandingkan dengan masalah pencurian hal tersebut telah jelas diatur dalam Alqur"ean (QS Al-Maidah (5):38) yaitu: “Adapun orang laki-laki maupun perempuan yang mencuri, potonglah tangan keduanya (sebagai) balasan atas perbuatan yang mereka lakukan dan sebagai siksaan dari ALLAH. Dan ALLAH Maha perkasa, Maha bijaksana.” Tetapi yang mungkin ada kesamaan dengan masalah korupsi adalah bahwa dalam agama Islam melindungi harta milik dan

\footnotetext{
${ }^{9}$ Suyitno, korupsi, op.cit ., hlm 132-134

${ }^{10}$ Suyitno, loc.cit.
} 
oleh karenanya mengharamkan caracara yang bathil dalam penguasaan harta milik sebagaimana disebutkan dalam (QS. Al-Baqarah $\{2\}: 188$ ) yaitu: “Dan janganlah kamu makan harta diantara kamu dengan jalan yang bathil, dan janganlah kamu menyuap dengan harta itu dengan para hakim, dengan maksud agar kamu memakan sebagian harta orang lain itu dengan jalan dosa, padahal kamu mengetahuinya." Berdasarkan hal tersebut terhadap tindak pidana korupsi ini tidak dapat dikenakan hukuman had, namun demikian walaupun tidak dikenakan hukuman hadd, bukan berarti tindak pidana korupsi bisa lepas dari hukuman, karena perbuatan tersebut telah jelas-jelas telah mengganggu kemaslahatan umum, sehingga dapat dikategorikan sebagai jarimah ta ${ }^{\text {ee }}$ zir. $^{11}$

Timbul kemudian persolan bahwa fikih mesti mempunyai suatu rumusan yang jelas tentang tindak pidana korupsi, karena tindak pidana ini menurut penulis lebih berbahaya dari pada pencurian dilihat dari motifnya, dimana salahsatu penyebab bertambahnya kemiskinan di Negara kita adalah disebabkan oleh korupsi, dan biasa nya dilakukan dengan motif keserakahan serta adanya penyalahgunaan dari tanggungjawab yang diberikan, sedangkan masalah pencurian biasanya karena persoalan ekonomi, serta adanya sebuah ketidakadilan dalam masyarakat, dan yang bermasalah dalam penyusunan fikih Islam menurut penulis salahsatu karena defenisi tentang korupsi dalam hukum positif sangat luas bukan hanya persolan suap-menyuap, tetapi juga masalah Kerugian keuangan/ perekonomian Negara, pengelapan dalam jabatan, perbuatan curang, pemerasan, grativikasi, benturan kepentingan dalam pengadaan.

Berdasarkan hal tersebut dalam pembangunan suatu fikih, termasuk fikih anti korupsi maka hal ini ada kaitannya dengan masalah filsafat hukum, ada dua teori yaitu: Pertama, teori yang mengatakan bahwa moral dan hukum harus berdampingan dalam arti tidak dapat dipisahkan, karena moral adalah inti atau pokok dari hukum, pandangan ini didukung seperti Friedman menyatakan bahwa hukum tidak akan pernah ada pemisahan secara total antara hukum dan moral bahkan ada keterkaitan dalam setiap masyarakat, misalnya dalam masyarakat liberal akan lebih mudah merefleksikan berbagai nilai moral ketimbang masyarakat otoriter, sedangkan dalam masyarakat yang terikat dengan tradisi akan ada transformasi tingkah laku sosial yang secara gradual menjadi tradisi hukum dan akhirnya akan menjadi rumusan legislatif. Sedangkan menurut Immanuel Kant menyatakan hukum moral adalah hukum dalam arti yang sebenarnya, olehnya itu hukum yang terpisah dari dari moral sesungguhnya bukanlah hukum dan tidak akan bertahan lama dan dikalangan pemikir hukum di Indonesia teori ini di dukung oleh Hazairin mengatakan

\footnotetext{
${ }^{11}$ Ibid, hlm 78
} 
hukum tanpa moral adalah kezaliman, sedangkan moral tanpa hukum adalah utopia. Kedua, teori yang mengatakan bahwa antara hukum dan moral mempunyai bidang masing-masing yang tidak ada hubungan sama sekali, pandangan ini didukung oleh paham positivisme.

Kalau kita proyeksikan kepada hukum Islam atau fikih, maka tentu saja sejalan dengan teori pertama bahwa hukum dan moral tidak dapat dipisahkan, bahkan moral adalah dasar atau pokok dari ajaran hukum atau fikih tersebut, sebagaimana dari pernyataan Nabi "Innama bu "itstu li utammima makarima al-akhlaq" bahwa moral adalah inti dari aturan-aturan yang mengatur tingkah laku manusia . Atas dasar pemikiran di atas, para teoritis Islam, mengartikan fikih sebagai pengetahuan tentang hukum syara ${ }^{e e}$ amaliyah yang diusahakan, dalam artian bahwa perumusan fikih ada unsur nalar manusia dalam memahami nash-nash hukum, dengan mempertimbangkan situasi kontekstual suatu masyarakat.

Selain mendasarkan pada nash-nash Al-quran dan sunah, maka perumusan fikih anti korupsi haruslah mengacu kepada paling tidak ada dua kerangka acuan, yaitu: pertama, Al-Amr al-A"ezham min al-mashlahah wa al-mafsadah, yakni perkara dominan dari pertimbangan kemaslahatan dan kemafsadatan, termasuk tentang nilai-nilai baik dan buruk seperti keadilan, kepercayaan masyarakat, penghianatan, kezaliman. Dan yang kedua adalah Ma tuqam bihi alhayat ad-dunya li al-hayat al-akhirah, yakni apapun yang dilakukan di dunia ini haruslah dikaitkan dengan konsekuensinya di akhirat, suatu acuan yang tidak ditemukan dalam perumusan hukumhukum sekuler. ${ }^{12}$ Hal tersebut juga penulis kaitkan dengan teori kedaulatan Tuhan oleh Abul A ${ }^{\mathrm{ce}} l \mathrm{a}$ al-Maududi (1903-1983) mengemukakan bahwa Tuhan merupakan Sang Maha Tunggal yang paling otoritatif dalam prinsip hukum, sehingga seluruh konsepsi tentang hukum yang bertentangan dengan ajaran Tuhan sebagai sumber hukum hendaknya ditolak, sebab kedaulatan Tuhan ini dapat diketahui melalui ajaran Wahyu yang disampaikan oleh Nabi-NYA, dan adapun pelaksanaan hukum Tuhan ini, menurutnya ada yaitu dua kelompok manusia, pertama yang menerima Tuhan sebagai Yang Maha Kuasa dan memberi acuan dalam kehidupan termasuk pelaksanaan hukuman, sedangkan kelompok yang kedua adalah kelompok yang menentang bahwa hukum itu urusan manusia bukan urusan Tuhan.

Namun Al-Maududi juga mengakui adanya kewenangan manusia untuk melaksanakan dan membentuk hukum sepanjang tidak ada dalam nash, dalam pelaksanaan hukum tersebut dengan menggunakan metode ijtihad, jadi teori yang dikembangkan oleh Al-Maududi itu pada hakekatnya

\footnotetext{
12 Ibid, hlm 130-133
} 
bersifat lentur dan tidak rigid sesuai dengan almaslahah al-,,ammah (kepentingan hidup manusia) yang pelaksanaanya dilakukan oleh manusia dengan panduan Tuhan. Dalam konsepsi Al-Maududi terdapat ide hukum yang bersifat permanen untuk menjaga eksistensi manusia dan kemuliaannya, dan ide hukum yang bersifat temporer dibatasi ruang dan waktu yang membutuh-kan pemikiran atau ijtihad ${ }^{13}$.

Berdasarkan uraian diatas maka sudah seharusnya ada pengaturan hukum fikih yang jelas untuk masalah korupsi. Menurut penulis khususnya dalam konteks negara kita perumusan mengenai fikih anti korupsi diperlukan untuk menjadi acuan dalam penegakan hukum (law enforcement) dan langkah awal yang dilakukan adalah dengan penciptaan landasan ontologi yang berdasar pada nilai-nilai yang berasal dari Al-Qureean dan hadist yang menjadi Manzilah atau sukma hukum dalam penciptaan fikih korupsi, sehingga orientasi yang dituju sesuai dengan nilainilai dalam Manzilah hukum tersebut.

Dalam konteks kenegaraan kita sekalipun kita tidak menganut sistem hukum Islam secara total, tetapi dinegara kita menganut sistem hukum yang abu-abu seperti sistem Eropa Kontinental, Anglo Saxon, hukum islam serta hukum adat, olehnya itu hukum islam juga mempunyai peran dan tempat, ketakutan penulis kemudian adalah karena syara ${ }^{\text {ee }}$ tidak menentukan macam-macam hukuman untuk tiap-tiap jarimah ta ${ }^{e e}$ zir salahsatunya adalah korupsi, tetapi hanya menyebutkan sekum-pulan hukuman dari yang ringan sampai kepada yang seberat-beratnya, jadi dalam hal ini penguasa diberi kebebasan untuk menentukan hukuman sesuai kepentingan masyarakat dan tidak boleh bertentangan dengan ketentuan syariat dan prinsip-prinsip yang umum. ${ }^{14}$

Selain itu dalam konteks negara kita ketika hal tersebut diserahkan kepada pemerintah akan timbul masalah seperti ketidakadilan didepan hukum (equality before the law), hal ini terjadi dalam realitas hari ini bahwa mereka yang melakukan korupsi banyak yang lepas dari jeratan hukum dan sekalipun mendapat hukuman, vonisnya paling satu atau dua tahun dibanding dengan masyarakat yang melakukan pencurian, mereka mendapat hukuman yang hampir sama dan juga mendapat hukuman secara psikologi, seperti dikucilkan dari masyarakat berbeda dengan koruptor, dalam hal ini terjadi sebuah ketidakadilan seperti yang dikatakan John Rawls bahwa keadilan sosial sebagai

${ }^{13}$ Sidik Tono, Wasiat Wajibah Sebagai Alternatif Mengakomodasi Bagian Ahli Waris Non-Muslim Di Indonesia, Desertasi disampaikan di ceramah promosi Doktor, Universitas Islam Indonesia, Yogyakarta, 7 Desember 2013, hlm 20-21

${ }^{14}$ Ibid, hlm79 
the difference dan principle of fair equality of oppurtunity, bahwa perbedaan sosial dan ekonomi harus diatur agar memberi manfaat yang paling besar bagi mereka yang kurang beruntung. ${ }^{15}$

Jadi menurut penulis ada sebuah ketidakadilan dalam penanganan korupsi khususnya dalam hal sanksi hukuman, sehingga tidak ada efek jera yang aksesnya bukan hanya korupsi yang semakin bertambah tetapi juga ada diskriminasi dalam hal hukum karena adanya perbedaan sosial dan ekonomi, olehnya itu menurut penulis untuk menghilangkan ketidakadilan itu maka hal yang esensial adalah terkait dengan masalah sanksi hukuman demi pertimbangan kemaslahatan umat manusia, sesuai teori keadilan Madjid khadduri yang membagi keadilan menjadi dua yaitu, keadilan substansi yakni keadilan yang melekat pada isi hukum yang dibuat dan sebagai sumber kemaslahatan, sebab hukum dibuat untuk tujuan kebaikan dan menghilangkan keburukan (mendatangkan maslahat dan menghilangkan kemudharatan) dan keadilan prosedural yang didasarkan aspek eksternal hukum biasanya melalui aspek keadilan formal. ${ }^{16}$

Berdasarkan beberapa teori diatas maka menurut penulis hal yang pertama yang harus dilakukan adalah mengidentifikasi mudharat dari korupsi ini seperti salah satu penyebab kemiskinan di negara ini, merajalelanya korupsi dihampir semua departemen, partai politik bahkan lembaga yang kita anggap suci atau sebagai the guardian of constitution (MK) terlibat korupsi dan juga menjalar ke daerah dengan melibatkan beberapa kepala daerah, selain itu hampir disetiap media massa selalu menampilkan korupsi yang tentunya menjadi pelajaran yang buruk bagi masyarakat, yang paling ironis adalah korupsi seakan menjadi budaya dan yang paling berbahaya adalah korupsi ini telah merusak tatanan negara. Maka menurut penulis hal yang harus dilakukan untuk menciptakan keadilan di negara ini sesuai dengan teori keadilan Madjid Khadduri dengan pertimbangan kemaslahatan maka harusnya sanksi untuk pelaku koruptor adalah hukuman mati, dengan mempertimbangkan kriteria serta dampak korupsi yang dilakukan, seperti apa yang pernah dipraktekkan Rasululllah pada masa awal Islam berkembang, yaitu keengganan Beliau untuk menyalati koruptor, dan menyatakan bahwa sadaqah dari hasil korupsi tidak akan diterima oleh Alllah Swt., pengancaman Beliau terhadap siapa saja yang melindungi koruptor, serta penjelasan bahwa korupsi adalah perbuatan yang memiliki dosa besar dan sekecil apapun tindakan korupsi akan mengantarkan pelakunya ke neraka ${ }^{17}$, selain itu perilaku koruptor dapat menimbulkan

${ }^{15}$ Sidik Tono, Wasiat Wajibah ... op. cit ., hlm 51

${ }^{16}$ Ibid ., hlm 50

${ }^{17}$ Jawahir Thontowi, Seminar ... op. cit., hlm 12 
kekacauan dalam interaksi dan relasi sosial, serta mengancam stabilitas masyarakat. Mereka layak divonis dengan Firman Allah Swt: "Sesungguhnya pembalasan terhadap orang-orang yang memerangi Allah dan Rasul-nya dan membuat kerusakan di muka bumi, hanyalah mereka dibunuh atau disalib, atau dipotong tangan dan kaki mereka dengan bertimbal balik atau dibuang dari negeri (tempat kediamannya),yang demikian itu sebagai suatu penghinaan untuk mereka di dunia, dan di akhirat mereka memperoleh siksaan yang besar. (QS. AL-Maidah (5):33). ${ }^{18}$

Berdasarkan hal tersebut menurut penulis hukumam mati sangat tepat diterapkan, selain itu hal ini bisa menjadi pertimbangan untuk pembentukan fikih anti korupsi kedepannya, supaya hal tersebut bisa menjiwai hukum positif di negara Indonesia dan terjewantahkan dalam UndangUndang untuk mengakomodasi hukuman mati untuk para pelaku koruptor.

\section{PENUTUP}

Adapun simpulan dari tulisan ini adalah:

1. Perbuatan korupsi adalah perbuatan kotor, curang dan buruk baik ditinjau dari hukum positif maupun hukum dari persfektif hukum islam.

2. Penyebab korupsi menurut penulis ada dua secara internal dan secara eksternal, tetapi yang juga harus diperhatikan adalah faktor internal denga menghadirkan kecerdasan spritual atau kata hati serta melalui perbaikan kualitas shalat.

3. Sekalipun belum ada fiqih anti korupsi dalam agama, diharapkan kedepannya dapat diupayakan supaya dalam pembuatan aturan positif dijiwai oleh semangat religiusitas.

4. Hukuman mati perlu untuk tindak pidana korupsi dengan pertimbangan kemaslahatan.

\section{DAFTAR PUSTAKA}

Ary Ginanjar Agustian, Emotional Spritual Quotient, Jakarta : Arga ,2001.

Husain Husain Syahatah, Ar-Rasywah Fi Mizan Asy-Syarie ah Al-Islamiah, Terjemahan, Kamran As ${ }^{e e}$ ad Irsyady, Suap dan Korupsi Dalam persfektif syariah, cetakan kedua, Jakarta: Sinar Grafika, 2008.

Jawahir Thontowi, seminar nasional dan call for paper dengan tema "peran perguruan tinggi atas destruksi moral perilaku koruptif: mengikis atau membudayakan?, Rabu, 4 Desember 2013 di ruang Auditorium gedung C lt.3, kampus Universitas Pekalongan. Jawa Tengah, hlm 610 Komisi Pemberantasan Korupsi, Memahami untuk membasmi, cetakan ke-dua Jakarta:Perpustakaan nasional, 2006.

\footnotetext{
${ }^{18}$ Husain Husain Syahatah, Ar-Rasywah Fi Mizan Asy-Syarieeah Al-Islamiah, Terjemahan, Kamran As ${ }^{\text {ee }}$ ad Irsyady, Suap dan Korupsi Dalam persfektif syariah, cetakan kedua (Jakarta: Sinar Grafika, 2008),hlm 19
} 
Marwan Effendy, Temu nasional komunitas masyarakat sriwijaya dengan tema strategi penanggulangan korupsi secara integral dan sistemik, 9 juni 2012 di Yogyakarta.

Sidik Tono, Wasiat Wajibah Sebagai Alternatif Mengakomodasi Bagian Ahli Waris Non-Muslim Di Indonesia, Desertasi disampaikan di ceramah promosi Doktor, Universitas Islam Indonesia, Yogyakarta, 7 Desember 2013

Suyitno, Korupsi, Hukum dan Moralitas Agama. Yogyakarta:Gama Media, 2006. UU No.31 tahun 1999 Tentang Korupsi 